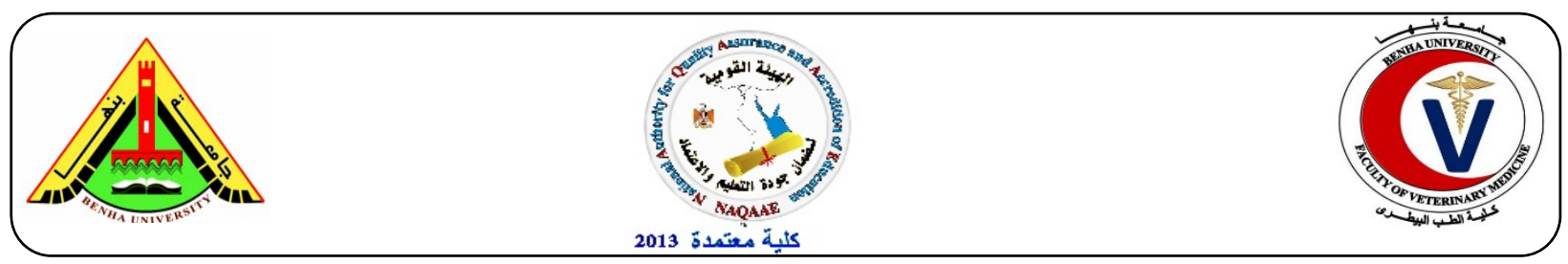

\title{
Biochemical effect of $\beta$-hydroxy- $\beta$-methylbutyrate calcium and creatine supplementations on some blood parameters, pro-inflammatory cytokines and growth performance of broiler chicks
}

\author{
Mohamed K. Mahfouz ${ }^{1}$, Kamel A. M. Zyan ${ }^{2}$ and Hossam H. Abdel-Hamid ${ }^{1}$ \\ ${ }^{1}$ Department of Biochemistry, and ${ }^{2}$ Department of Poultry Diseases, Faculty of Veterinary Medicine, \\ Benha University, Egypt.
}

\section{A B S T R A C T}

One hundred and sixty-five one-day old Cobb broiler chicks were allocated into 3 groups to investigate the effect of dietary $0.1 \% \beta$-hydroxy- $\beta$-methylbutyrate calcium (HMB) and $0.1 \%$ creatine on some blood parameters, pro-inflammatory cytokines and growth performance parameters in terms of total feed intake (TFI), total body weight gain (TBWG), total body weight and feed conversion ratio (FCR) during certain time intervals $\left(21^{\text {st }}\right.$ day and $42^{\text {nd }}$ day) versus control group ( 0 treatment). Some biochemical changes were recorded at the $42^{\text {nd }}$ day among creatine supplemented group in the form of significantly high results of both triglycerides and T3 in group 3 (creatine) than that of the control group on the same day at P value $>0.05$. HMB supplemented group showed significantly lower results of ALT (mean) than that of control group at $(P$ value $>0.05)$ on the $21^{\text {st }}$ day which became insignificant at the $42^{\text {nd }}$ day. Dietary $0.1 \%$ HMB-Ca recorded better growth performance parameters in terms of TFI (4.527), TBWG (2.515), TBW (2.555) and TFCR (1.8) if compared to creatine supplemented group of $(4.664,2.508,2.549$ and 1.86) respectively and the control group of TFI equaled to 4.7432, TBWG equaled to 2.156 , TBW equaled to 2.1987 and TFCR equaled to 2.2 at the end of the experiment. HMB and creatine supplementations had no effect on other blood parameters, viz. AST, urea, creatinine, total protein, FFA, T4, T3/T4 ratio, TSH, uric acid, cholesterol, HDL and LDL, and pro-inflammatory cytokines namely IL-6, IL-2 and TNF- $\alpha$.

Keywords: HMB-Ca, Creatine, Broiler chicks, TFI, FCR, TBWG, TBW.

(BVMJ-30(1): 39-50, 2016)

\section{INTRODUCTION}

$\beta$ -Hydroxy- $\beta$-methylbutyrate (HMB) is a bioactive metabolite formed from the breakdown of the essential branched amino acid, leucine. Leucine and its metabolite, keto-isocaproate (KIC), appear to inhibit protein degradation. This antiproteolytic effect is believed to be mediated by HMB (Portal et al., 2011), which has gained interest in the animal and human research field in the last two decades. In domestic animals, HMB has been shown to convey beneficial effects in various species.
Nissen et al. (1994a) first discovered that feeding HMB to broiler chickens resulted in faster growth rate, reduction in mortality, and increase in muscle deposition. The same research group also obtained positive results with HMB such as increasing body mass in growing lambs (Nissen et al., 1994b), and improving carcass yield in feedlot steers (Van-Koevering et al., 1994). Subsequently, extensive studies have been conducted on HMB supplementation in protein metabolism. Inclusion of HMB was reported 
to suppress the protein degradation in isolated rat and chick muscles (Ostaszewski et al., 2000). Currently, HMB is widely used as an ergogenic supplement mainly in bodybuilders and power athletes who seek to improve performance or enlarge muscle mass (Portal et al., 2010). On the other side, human studies have shown that creatine monohydrate $(\mathrm{CrM})$ supplementation has a number of biochemical and physiological effects. Intracellular phosphocreatine (PCr) functions as an energy buffer to prevent ATP depletion in the skeletal muscle (Robertson et al., 2003). Thus, creatine ( $\mathrm{Cr}$ ) is heavily involved in energy metabolism through the $\mathrm{Cr}$ and phosphocreatine (PCr) system. This system functions as a backup to the adenosine diphosphate/adenosine triphosphate (ATP) cycle to store and mobilize energy when required. The animal's demand for $\mathrm{Cr}$ can be supplied either directly from animal protein (e.g., fish or animal byproduct meal) in the diet or by endogenous synthesis. In the last 20 years, $\mathrm{Cr}$ has become a very popular dietary supplement (Maughan et al., 2004). Recent findings also highlight the effect of $\mathrm{Cr}$ supplementation on the increase of skeletal muscle and brain total $\mathrm{Cr}$ and $\mathrm{PCr}$ concentrations with an even greater degree of increase seen in organs with low baseline $\mathrm{Cr}$ content such as kidney and liver (Ipsiroglu et al., 2001). In animals, the effects of $\mathrm{Cr}$ supplementation on renal and hepatic structure and function have not been well established. Whereas some studies did not report any alteration in renal and hepatic function after $\mathrm{Cr}$ supplementation (Taes et al., 2003; Tarnopolsky et al., 2003), others have observed that it can speed up renal and hepatic disease progression (Tarnopolsky et al., 2003; Ferreira et al., 2005). Data on the influence of HMB and creatine supplementations, particularly on blood parameters and pro-inflammatory cytokines, are still scarce and inconsistent in broiler chicks. The aim of the current research was to investigate the biochemical effect of $\mathrm{HMB}$ and creatine on some blood parameters, proinflammatory cytokines as well as the effect of each other on growth performance (total feed intake (TFI), total body weight gain (TBWG), total body weight (TBW) and feed conversion ratio) in broiler chicks at certain time intervals $\left(21^{\text {st }}\right.$ day and $42^{\text {nd }}$ day).

\section{MATERIAL AND METHODS}

\subsection{Birds and experimental design:}

One hundred and sixty-five one-day old Cobb broiler chicks were commercially obtained and allocated into 3 groups to 3 dietary treatment (supplementation) groups; 1control group ( 0 treatment), $2-0.1 \%$ betahydroxy-beta-methylbutyrate (HMB-Ca) (ISOLABS, USA) and $3-0.1 \%$ creatine (SAN Corporation, CA, USA). Each treatment group had 55 chicks. All groups were housed into three separate ventilated rooms and maintained on a 24 -h constant-light program and temperature. Birds were fed on wellbalanced diet as described by NRC (1994). Starter diet was given till the $14^{\text {th }}$ day of age after that chicks were fed on grower diet which was given till the $28^{\text {th }}$ day of age when chicks were then fed on finisher diet till the end of the experiment ( $42^{\text {nd }}$ day of age). Feed and water were provided ad libitum throughout the experiment.

\subsection{Growth performance parameters:}

Feed intake (FI): The FI was calculated by dividing the amount of feed consumed in gram (by a certain group) during the week by the number of chicks of this group during the same week, where the TFI was only recorded. Body weight gain: The gain in body weight per week was calculated by subtracting the body weight between the two successive weeks, where the total body weight gain (TBWG) was the only recorded at the end of the experiment. Body weight was monitored at certain time (weekly to the $6^{\text {th }}$ week), where the total body weight (TBW) was the 
only recorded at the end of the experiment. Feed conversion ratio (FCR) was calculated by dividing the average amount of feed consumed in grams (per a chick) during the week by the average weight gain in grams during the same week (Lambert et al., 1936). $\mathrm{FCR}=$ average feed intake $(\mathrm{g})$ bird per week/ average body weight gain (g) bird per week, where the only TFCR was recorded.

\subsection{Blood sampling:}

Blood samples were collected from the jugular vein at the $21^{\text {st }}$ and $42^{\text {nd }}$ days of age where five chicks were randomly taken from each group. Blood samples were then allowed to clot by leaving it undisturbed at room temperature for 15-30 minutes. Serum samples were separated after centrifuging at $1800 \mathrm{rpm}$ for 10 minutes and then divided into small aliquots and stored at $-20^{\circ} \mathrm{C}$ until examined.

\subsection{Blood parameters:}

Liver function tests (ALT and AST) which were performed according to Young (2001). Total proteins and uric acid were performed according to Tietz (1995) and Young (2001). Kidney function tests (creatinine and urea) were performed according to Burtis et al. (1999). Lipid profiles (cholesterol, triglyceride, HDL and LDL) were performed according to Kaplan (1984), Young (1995) and Young (2001). Thyroid gland functions: Thyroid stimulating hormone (TSH) ELISA kit: A competitive enzyme immunoassay technique for quantitative determination of chicken TSH concentrations in serum and plasma. The microtiter plate provided in this kit has been pre-coated with an antibody specific to $\mathrm{TSH}$. It is a commercial kit obtained from BioSource Company (San Diego, CA, USA). Chicken thyroxine (T4) ELISA kit: It is a double antibody sandwich ELISA Kit. Microtiter plates were pre-coated with chicken T4 monoclonal antibody and the detecting antibody was polyclonal antibody labeled with biotin. This kit was made for in vitro quantitative detection in chicken serum, plasma or cell culture supernatant and organizations in the natural and recombinant T4 concentration. The kit was obtained from BioSource Company, San Diego, CA, USA. Chicken Triiodothyronine (T3) ELISA kit: It is a competitive enzyme immunoassay utilizing a monoclonal anti-T3 antibody and a T3-HRP conjugate. This T3 ELISA kit is a 1.5 hour solid-phase ELISA designed for the quantitative determination of Chicken T3. It was obtained from BioSource Company, San Diego, CA, USA. Chicken Free Fatty Acid (FFA) ELISA kit: It is a competitive enzyme immunoassay utilizing a monoclonal antiFFA antibody and an FFA-HRP conjugate. This FFA ELISA kit is a 1.5 hour solid-phase ELISA designed for the quantitative determination of Chicken FFA. It was obtained from BioSource Company, San Diego, CA, USA.

Pro-inflammatory cytokines: Chicken Interleukin2 (IL-2) ELISA kit: It is quantitative sandwich enzyme immunoassay technique. Antibody specific for IL-2 has been pre-coated onto a microplate. This kit was used for quantitative determination of chicken interleukin 2 (IL-2) concentration in serum, plasma and tissue homogenates. It is a commercial kit obtained from BioSource Company (San Diego, CA, USA). Chicken Interleukin 6 (IL-6) ELISA kit: It is a sandwich-ELISA applied in vitro for quantitative determination of Chicken IL-6 concentrations in serum, plasma and other biological fluids. The micro ELISA plate provided in this kit has been pre-coated with an antibody specific to IL-6. It was obtained from BioSource Company, San Diego, CA, USA. Chicken TNF- $\alpha$ (Tumor Necrosis Factor Alpha) ELISA Kit: It is a sandwichELISA applied in vitro for quantitative determination of chicken TGF- $\beta 1$ concentrations in serum, plasma and other biological fluids. The micro ELISA plate provided in this kit has been pre-coated with an antibody specific to TGF- $\beta 1$. The kit was 
obtained from BioSource Company, San Diego, CA, USA.

\subsection{Statistical analysis:}

All the following analyses were performed using $\mathrm{IBM}^{\circledR}$ SPSS $^{\circledR}$ Statistics, Version 21, IBM Corporation, 2012, under the environment of Windows ${ }^{\circledR}$ 8.1, Microsoft Corporation. Two-way analysis of variance (ANOVA): Raw data were statistically tested for the normal distribution using SPSS different statistical parameters. Unfortunately, the assumption of normal distribution of data was violated (right Skewness) as indicated by the SPSS' Shapiro-Wilk and Kolmogorov-Smirnov tests at $\mathrm{P}<0.05$. Data were then transformed using $\log$ base $10+1$ to follow normal distribution. Two-way ANOVA with post hoc test using the least significant difference (LSD) were used to study the statistical significant differences in the means of phases; phase 1 (21 day old) and phase 2 (42 day old chicks), blood parameters \& proinflammatory cytokines categories and the interaction between each other as independent factor and their effect on results in chickens as dependent factor and to study the statistical significant differences in the means of growth performance parameters (TFI, TBWG, TBW and FCR) of control group as well as treatment groups at the end of the experiment ( $42^{\text {nd }}$ day).

\section{RESULTS:}

Two-way ANOVA was performed on transformed raw data. It revealed statistically significant differences of blood parameters and pro-inflammatory cytokines during the 2 phases ( $21 \mathrm{~d}$ and $42 \mathrm{~d}$ ) at $\mathrm{P}$ value less than 0.05 , as shown in Table (1), Figure (1) and (2). To specify where the statistical significant differences are located, pairwise comparisons were done in the form of post hoc test (group of $T$ tests) using LSD at $P<$ 0.05 and confidence interval of $95 \%$ for blood parameters \& pro-inflammatory cytokines categories within time intervals $(21 \mathrm{~d}$ and 42 d) as in Table (2). This revealed low statistically significant differences in the means of ALT between the control group and group $2(\mathrm{HMB})$ at the $21^{\text {st }}$ day, where the results of ALT (mean) were significantly higher in the control group than in group 2 (HMB) at $\mathrm{P}=0.031$. Then again, the significant results obtained at the $21^{\text {st }}$ day between the control group and group 2 of ALT parameter became insignificant at the $42^{\text {nd }}$ day $(P$ value $>0.05)$. Once again, there was high statistically significant differences in the means of triglycerides at the $42^{\text {nd }}$ day between the control group and group 3 (creatine) at $P$ value $=0.001$, where the result (mean) of triglycerides was significantly higher in group 3 (creatine) than that of the control group. There were statistically significant differences in the means of $\mathrm{T} 3$ between the control group at the $42^{\text {nd }}$ day and group 3 (creatine) at $\mathrm{P}$ value of 0.000 , indicating significantly higher results (mean) of T3 in group 3 (creatine) than those of control group). Table (3) specifies where the statically significant differences of weight between treatment groups were located, where a post hoc test (pairwise comparison) using LSD at $p<0.05$ and confidence interval of $95 \%$ was performed. Very high statistically significant variation was noticed between the control group as well as the treatment group and between treatment groups each other at $P=0.000000$ throughout the experiment, where the recorded overall mean differences of weight were significantly higher in treatment groups than in the control group and in group 2 (HMB) than that of group3 (creatine). Moreover, the overall weight mean difference was significantly better between the control group and group 2 (HMB) than that between the control group and group 3 (creatine). The increased total body weights were significantly higher at the $6^{\text {th }}$ week in HMB supplemented group (2.555 $\mathrm{Kg}$ ) than that of creatine supplemented group 
Table (1). Comparison of blood parameters and pro inflammatory cytokines' average means during certain intervals of the experiment

\begin{tabular}{|c|c|c|c|c|c|c|}
\hline \multirow{2}{*}{$\begin{array}{c}\text { Blood parameter \& } \\
\text { pro-inflammatory cytokines }\end{array}$} & \multicolumn{3}{|c|}{$21^{\text {st }}$ day } & \multicolumn{3}{|c|}{$42^{\text {nd }}$ day } \\
\hline & $\begin{array}{c}\mathrm{G} 1 \\
\text { (control) }\end{array}$ & $\begin{array}{c}\mathrm{G} 2 \\
(\mathrm{HMB})\end{array}$ & $\begin{array}{c}\mathrm{G} 3 \\
\text { (creatine) }\end{array}$ & $\begin{array}{c}\mathrm{G} 1 \\
\text { (control) }\end{array}$ & $\begin{array}{c}\mathrm{G} 2 \\
(\mathrm{HMB})\end{array}$ & $\begin{array}{c}\text { G3 } \\
\text { (creatine) }\end{array}$ \\
\hline ALT & $9.4 \pm 2.07^{\mathrm{a}}$ & $6 \pm 2.73^{\mathrm{a}, \mathrm{b}}$ & $8.2 \pm 3.34^{b, c}$ & $6.4 \pm 1.14^{\mathrm{a}, \mathrm{b}}$ & $5.2 \pm 2.48^{\mathrm{a}}$ & $6 \pm 3.00^{\mathrm{a}}$ \\
\hline AST & $153.4 \pm 15.50^{\mathrm{a}}$ & $144 \pm 8.71^{\mathrm{a}, \mathrm{b}}$ & $153.2 \pm 11.30^{\mathrm{a}}$ & $152.4 \pm 9^{\mathrm{a}}$ & $137.8 \pm 16^{\mathrm{b}, \mathrm{c}}$ & $157.8 \pm 8.58^{\mathrm{a}}$ \\
\hline Total protein & $2.25 \pm 0.38^{\mathrm{a}, \mathrm{b}}$ & $2.17 \pm 0.56^{\mathrm{a}}$ & $2.32 \pm 0.18^{\mathrm{a}}$ & $2.90 \pm 0.33^{\mathrm{a}}$ & $3.65 \pm 0.23^{\mathrm{a}}$ & $2.75 \pm 0.23^{\mathrm{a}}$ \\
\hline Creatinine & $0.34 \pm 0.046^{\mathrm{a}}$ & $0.29 \pm 0.019^{\mathrm{a}}$ & $0.28 \pm 0.054^{\mathrm{a}}$ & $0.38 \pm 0.037^{\mathrm{a}}$ & $0.32 \pm 0.053^{\mathrm{a}}$ & $0.31 \pm 0.033^{\mathrm{a}}$ \\
\hline Urea & $8.2 \pm 0.83^{\mathrm{a}}$ & $7.2 \pm 1.64^{\mathrm{a}, \mathrm{b}}$ & $10 \pm 1.22^{\mathrm{a}, \mathrm{b}}$ & $8.2 \pm 0.44^{\mathrm{a}}$ & $7 \pm 0.70^{\mathrm{a}}$ & $8.8 \pm 1.09^{\mathrm{a}}$ \\
\hline Uric acid & $7.8 \pm 0.60^{\mathrm{a}}$ & $5.4 \pm 0.13^{\mathrm{a}}$ & $7.5 \pm 0.19^{\mathrm{a}}$ & $8.24 \pm 0.35^{\mathrm{a}}$ & $6.74 \pm 0.40^{\mathrm{a}}$ & $6.44 \pm 0.25^{\mathrm{a}}$ \\
\hline Cholesterol & $114.2 \pm 13.4^{\mathrm{a}}$ & $116.6 \pm 10.5^{\mathrm{a}}$ & $118 \pm 15.1^{b}$ & $133.2 \pm 8.52^{b}$ & $137.6 \pm 14.9^{\mathrm{a}}$ & $138.6 \pm 31^{\mathrm{b}}$ \\
\hline Triglyceride & $62.2 \pm 5.80^{\mathrm{b}}$ & $72.2 \pm 14.80^{\mathrm{b}, \mathrm{c}}$ & $61 \pm 18.73^{\mathrm{a}}$ & $62.4 \pm 17.81^{\mathrm{a}}$ & $52.8 \pm 5.71^{\mathrm{b}}$ & $102.6 \pm 12.5^{b}$ \\
\hline HDL & $82.26 \pm 4.43^{\mathrm{a}}$ & $85.76 \pm 4.08^{\mathrm{a}}$ & $89.26 \pm 8.13^{\mathrm{a}}$ & $66.76 \pm 1.78^{\mathrm{a}}$ & $69.76 \pm 1.08^{\mathrm{a}}$ & $58.26 \pm 2.2^{\mathrm{a}}$ \\
\hline LDL & $19.5 \pm 16.24^{\mathrm{a}}$ & $16.6 \pm 12.48^{a}$ & $16.5 \pm 10.75^{\mathrm{a}, \mathrm{b}}$ & $53.96 \pm 10.41^{\mathrm{b}}$ & $57.28 \pm 15.6^{\mathrm{b}}$ & $59.82 \pm 30.6^{\mathrm{a}}$ \\
\hline $\mathrm{T} 3$ & $17.10 \pm 5.32^{\mathrm{a}}$ & $25.55 \pm 19.8^{\mathrm{a}, \mathrm{c}}$ & $18.42 \pm 5.81^{\mathrm{a}, \mathrm{b}}$ & $18.44 \pm 10.1^{\mathrm{a}}$ & $24.49 \pm 10.9^{\mathrm{a}}$ & $32.79 \pm 14.3^{\mathrm{a}}$ \\
\hline $\mathrm{T} 4$ & $21 \pm 6.34^{\mathrm{a}, \mathrm{c}}$ & $27.10 \pm 7.10^{\mathrm{a}}$ & $25.38 \pm 4.69^{\mathrm{a}, \mathrm{b}}$ & $30.8 \pm 6.7^{\mathrm{a}, \mathrm{c}}$ & $34.1 \pm 8.7^{\mathrm{a}}$ & $33.1 \pm 11.4^{\mathrm{a}}$ \\
\hline $\mathrm{T} 3 / \mathrm{T} 4$ ratio & $0.82 \pm 0.26^{\mathrm{a}}$ & $0.93 \pm 0.72^{b}$ & $0.70 \pm 0.13^{\mathrm{a}}$ & $0.56 \pm 0.19^{\mathrm{a}}$ & $0.71 \pm 0.25^{\mathrm{a}, \mathrm{b}}$ & $1.12 \pm 0.74^{\mathrm{a}}$ \\
\hline TSH & $1.64 \pm 0.31^{\mathrm{a}}$ & $1.86 \pm 0.45^{\mathrm{a}}$ & $1.61 \pm 0.39^{\mathrm{a}, \mathrm{b}}$ & $1.44 \pm 0.27^{\mathrm{a}}$ & $1.08 \pm 0.11^{\mathrm{a}}$ & $1.17 \pm 0.06^{\mathrm{a}}$ \\
\hline IL2 & $0.32 \pm 0.060^{\mathrm{a}}$ & $0.24 \pm 0.063^{\mathrm{a}}$ & $0.27 \pm 0.15^{\mathrm{a}}$ & $0.32 \pm 0.073^{\mathrm{a}, \mathrm{b}}$ & $0.22 \pm 0.033^{\mathrm{a}}$ & $0.28 \pm 0.049^{\mathrm{a}}$ \\
\hline IL6 & $30.43 \pm 6.74^{\mathrm{a}, \mathrm{b}}$ & $36.42 \pm 4.45^{\mathrm{a}}$ & $29.12 \pm 2.27^{b, c}$ & $27.8 \pm 5.05^{\mathrm{a}}$ & $24.5 \pm 9.59^{\mathrm{a}}$ & $29.7 \pm 11.3^{\mathrm{a}}$ \\
\hline TNF- $\alpha$ & $73.79 \pm 19.55^{\mathrm{a}}$ & $66.88 \pm 6.81^{\mathrm{b}, \mathrm{c}}$ & $74.54 \pm 16.76^{\mathrm{a}}$ & $85.6 \pm 21.6^{\mathrm{a}}$ & $57.7 \pm 20.3^{\mathrm{a}}$ & $41.5 \pm 12.9^{\mathrm{a}}$ \\
\hline FFA & $3.88 \pm 0.15^{\mathrm{a}}$ & $4.40 \pm 0.32^{b}$ & $3.51 \pm 0.93^{\mathrm{a}}$ & $5.66 \pm 0.65^{b}$ & $5 \pm 2.17^{\mathrm{a}}$ & $5.26 \pm 0.90^{\mathrm{b}}$ \\
\hline
\end{tabular}

Data are revealed as (Mean \pm S.E). S.E $=$ Standard error.

Mean values with superscript letters are statistically significant difference at $P<0.05$ 
Table (2). Post Hoc test (pairwise comparisons) using the least significant difference (LSD) to compare multiple mean differences of blood parameters and pro inflammatory cytokines within time intervals ( $21 \mathrm{~d}$ and $42 \mathrm{~d}$ ).

\begin{tabular}{ccccc}
\hline Phases & $\begin{array}{c}\text { (i) Blood parameters \& } \\
\text { pro inflammatory } \\
\text { cytokines }\end{array}$ & $\begin{array}{c}\text { (j) Blood parameters \& } \\
\text { pro inflammatory } \\
\text { cytokines }\end{array}$ & $\begin{array}{c}\text { Mean difference (i- } \\
\text { j) }\end{array}$ & ${\text { (P value })^{\mathrm{b}}}^{\mathrm{b}}$ \\
\hline (21 d) & G1 (ALT) & G2 (ALT) & $0.1992 \pm 0.092^{\mathrm{a}}$ & 0.031 \\
$(42 \mathrm{~d})$ & G1 (Trig.) & G3 (Trig.) & $-0.2225 \pm 0.064^{\mathrm{a}}$ & .001 \\
\hline
\end{tabular}

a: The mean difference \pm Standard error: significant at $\mathrm{P}$ value less than 0.05 . b. Adjustment for multiple comparisons: Least Significant Difference (LSD).

Table (3): Post Hoc test (Pairwise Comparisons) using LSD to compare multiple mean differences of chick weights at certain time intervals

\begin{tabular}{cccc} 
Treatment groups (i) & Treatment groups (j) & $\begin{array}{c}\text { Overall mean (LG10) difference } \\
\text { of weight (i-j) }\end{array}$ & $(P \text { value })^{\mathrm{b}}$ \\
\hline G1 & G2 & $-180.2724 \pm 0.302^{\mathrm{a}}$ & 0.000000 \\
G1 & G3 & $-170.0057 \pm 0.302^{\mathrm{a}}$ & 0.000000 \\
G2 & G3 & $10.2667 \pm 0.303^{\mathrm{a}}$ & 0.000000 \\
\hline
\end{tabular}

Data are revealed as overall mean difference of weight (Mean \pm S.E). S.E $=$ Standard error Mean values with superscript letters are statistically significant at $P<0.05$.

Table (4) Total feed conversion ratio, total body weight gain, total body weights and total feed intake for control group as well as treatment groups at the end of the experiment.

\begin{tabular}{cccc}
\hline Performance parameters & G1 (control) & G2 (HMB) & G3(creatine) \\
\hline TFI & $4.743 \pm 0.037^{\mathrm{a}}$ & $4.527 \pm 0.098^{\mathrm{a}}$ & $4.664 \pm 0.090^{\mathrm{b}}$ \\
TBWG & $2.156 \pm 0.037^{\mathrm{a}}$ & $2.515 \pm 0.085^{\mathrm{a}}$ & $2.508 \pm 0.025^{\mathrm{a}}$ \\
Total FCR & $2.2 \pm 0.004^{\mathrm{a}}$ & $1.8 \pm 0.0076^{\mathrm{b}}$ & $1.86 \pm 0.008^{\mathrm{b}}$ \\
TBW & $2.198 \pm 0.010^{\mathrm{a}}$ & $2.555 \pm 0.015^{\mathrm{a}}$ & $2.549 \pm 0.032^{\mathrm{b}}$ \\
\hline
\end{tabular}

$($ Mean \pm S.E). TFCR $=$ total feed conversion ratio. $\mathrm{TBWG}=$ total body weight gain. $\mathrm{S} . \mathrm{E}=$ Standard error $\mathrm{TFI}=$ total feed intake. $\mathrm{TBW}=$ total body weight. Mean values with superscript letters are statistically significant at $P<0.05$. 
$(2.549 \mathrm{Kg})$, while the control group recorded a significant lower total body weight in comparison with other groups $(2.198 \mathrm{Kg})$. Table (4) and figure (3) record a better (significant) total feed intake (TFI), total body weight gain (TBWG), total body weight (TBW) and total feed conversion ratio (TFCR) in group 2 (HMB) and group 3 (creatine) of $(4.527,2.515,2.555$ and 1.8$)$ and (4.664, 2.507, 2.549 and 1.86) respectively specially if compared with the control group (group 1) of TFI equal to 4.743, TBWG equal to 2.156 and TBW equal to 2.198 and TFCR equal to 2.2 at the end of the experiment. In conclusion, group 2 (HMB) showed better performance followed by group3 (creatine). All treatment groups recorded significant TFI, TBWG, TBW and TFCR better than the control group.

\section{DISCUSSION}

Biochemical blood parameters are indicators for the physiological, pathological, and nutritional status of the animal. They have the potential of being used to elucidate the impact of nutritional factors and additives supplied in the diet (Ashour et al., 2014). Table (1) and Figures (1-2) reveal statistically significant differences (2-way ANOVA) of blood parameters, viz. AST, ALT, urea, creatinine, total protein, FFA, T3, T4, T3/T4 ratio, TSH, uric acid, cholesterol, triglycerides, HDL and LDL and pro inflammatory cytokines namely IL-6, IL-2 and TNF- $\alpha$ of chicks treated with $\mathrm{HMB}$, creatine and the combination of creatine and $\mathrm{HMB}$ in comparison of the control group ( 0 treatment) during certain time intervals $(21 \mathrm{~d}$ and $42 \mathrm{~d})$ at $P<0.05$. Table (2) revealed significantly higher results of ALT (mean) in the control group as compared to group 2 (HMB) with $\mathrm{P}$ value $=$ 0.031 on the $21^{\text {st }}$ day. This may be attributed to increased metabolic rate in the liver, indicating liver toxicity, especially when exposed to drugs, viral or bacterial agents (Takahashi et al., 1995). In the current study, vaccination against New Castle was carried out at the $20^{\text {th }}$ day of the experiment with Lasota strain, where it could be the reason why ALT was elevated. This finding is in agreement with the results reported by Khudair and Al-Hussary (2010), who denoted that vaccinated chickens showed a significant elevation in the level of globulin and activities of aspartate aminotransferase (AST), ALT and lactate dehydrogenase (LDH) compared with their values in nonvaccinated chickens. That finding (elevated ALT) fortunately became insignificant at the $42^{\text {nd }}$ day. There were no statistical significant differences recorded between the control group and the other treatment groups or between treatment groups with each other in ALT profile either at the $21^{\text {st }}$ day or the $42^{\text {nd }}$ day. Except for ALT significant changes was noticed between the control group and groups 2 (HMB), there were no significant changes recorded in blood parameters and proinflammatory cytokines at the $21^{\text {st }}$ day between the control group and the other treatment groups. High statistically significant differences in the mean of triglycerides was recorded at the $42^{\text {nd }}$ day between the control and group 3 (creatine) at $\mathrm{P}$ value $=0.001$, where the result (mean) of triglycerides was significantly higher in group 3 (creatine) than that of the control group as shown in Table (2). This finding contradicts the studies which reported that creatine had a little effect on lipid metabolism specially serum triglycerides in broilers as recorded by Chen et al. (2011) as well as the fact that creatine supplementation at doses of $0.5 \mathrm{~g} / \mathrm{kg} /$ day produced no significant changes in laboratory measurements of triglycerides compared to the control group in rats (Baracho et al., 2015). However, Earnest et al. (1996) reported decreased triglycerides $(26 \%)$ in hypercholesterolemic men and women (32 y to $70 \mathrm{y})$ supplemented with creatine $5 \mathrm{~g} /$ day for 56 days. The mechanism of creatine hypolipidaemic effects remains enigmatic, however, creatine may promote 
acute increases in peripheral and/or hepatic insulin sensitivity and/or post-receptor signaling in post prandial hyperglycemic non-diabetic subjects. This may faster decrease in de novo triglyceride production as stated by Steiner and Vranic, (1982). There was significant higher results (mean) of T3 in group 3 (creatine) than that of the control group. The mechanism through which creatine exerts its effects on thyroid hormones is yet to be investigated. These results are contrary to the results revealed by Moraes et al. (2014), who observed a reduction in plasma levels of $\mathrm{T} 3$ and an increase in T4 levels in healthy young adults, where the authors suggested that the main cause of lowering the plasma T3 level was the creatine supply which contributed to a compensatory reduction in T3 synthesis by decreasing the activity of the type 2 deiodinase responsible for tissue conversion of T4 to T3 in tissues such as the kidneys and skeletal muscles (Mullur et al., 2014), where, a week of creatine supplementation in diet significantly increased creatinine and creatine kinase (CK) plasma levels, and simultaneously reduced globulins and T3 plasms levels, mimicking a condition that characterizes impaired renal function. There were no significant changes recorded in blood parameter and pro inflammatory cytokines at the $42^{\text {nd }}$ day between the control group and other treatment groups rather than those mentioned before.

HMB supplemented group showed better performance in terms of better TFI and TBWG, TBW and TFCR followed by group 3 (creatine) as shown in Table (3). All treatment groups recorded significant growth performance parameters better than the control group. The reasons behind better performance of group 2 supplementary treated with HMB will be discussed as follows. Tendency in weight gain was observed when HMB was consumed at $0.1 \%$ (Peterson et al., 1999). Nissen et al. (1994) explained that the increase in performance of broilers fed a diet supplemented with HMB was possibly due to meeting the HMB requirement for metabolic function in those chicks. Studies have shown that administration of HMB into the amnion of late-term avian embryo beneficially affected chick BW (Uni et al., 2005; Foye et al., 2006b) through enhancing early gut development (Foye et al., 2006a). Furthermore, HMB may enhance chick growth by acting as an immune-modulator. For instance, Peterson et al. (1999) reported that HMB supplementation tended to improve several immunological functions in broilers, and speculated that such immunological improvement may enhance growth performance. HMB has also been adopted as an alternative supplement to combat protein degradation. Regarding meat producing livestock, the effects of HMB on different meat-producing animals are not consistent. In the present study, the chicks were fed HMB from day 1. A significant increase in average body weight was observed in chicks fed $0.1 \%$ HMB-Ca diet at both the 21 and the 42 days of age compared with chicks fed the control diet. In chickens, between 1 to 6 weeks of age, protein degradation was slower than protein synthesis as evidenced by increases in muscle growth during this period (Lauterio et al., 1986). It was suggested that HMB might affect muscle growth because it increased protein synthesis and decreased protein degradation (Uni et al., 2005). However, HMB-Ca supplementation did not significantly affect the leg muscle yield. Ostaszewski et al. (2000) reported that HMB appeared to suppress protein breakdown more in white muscle fibers than in red muscle fibers in the rat. The reason for this phenomenon may be attributed to the fact that the rate of protein turnover in different skeletal muscles varies with the composition of fiber types (Baillie and Garlick, 1991). It has been postulated that HMB may regulate protein metabolism either through hormonal 
receptor effects (Pause et al., 1994; Tsuruzoe et al., 1998 and Tatara, 2008), or it might be attributed to modulating the enzyme responsible for muscle tissue breakdown. Better growth performance recorded in the current research in group 2 supplemented with HMB matched the results of (Qiao et al., 2013).

Creatine monohydrate is an amino acid derivative that has become a popular sports supplement used to increase muscle performance (Wyss and Kaddurah-Daouk, 2000 ) in humans. The role of creatine in the better performance of group 3 (creatine) than that of the control group as recorded may be due to that the mechanisms suggest that creatine may enhance muscle performance and protein synthesis due to an increase in the amount of energy stored as phosphocreatine. Creatine loaded muscle has the capacity to maintain normal physiological function and to delay the onset of muscle fatigue (Casey et al., 1996). Increased concentrations of intramuscular phosphocreatine attract water into muscle cell and increase the cell volume (Hultman et al., 1996). Earlier research has suggested that creatine can help the body quickly provide ATP through the creatinephosphocreatine energy shuttle system, improve the muscle ATP concentration and buffer muscle lactic acid accumulation (Bessman and Carpenter, 1985). Additionally, creatine monohydrate increases bone mineral density (Antollic et al., 2007). Thus, creatine supplementation could be expected to increase weight gain and percentage lean. Balsom et al. (1995) showed that human athletes consuming $20 \mathrm{~g}$ of $\mathrm{CrM} /$ day for 6 days had increased body mass by $1.1 \mathrm{~kg}$ in the study done by Moghadam et al. (2008) to clarify the effects of creatine monohydrate (CrM) supplementation on growth performance and to evaluate histopathological lesions in rats and broiler chickens. The authors concluded that feeding $\mathrm{CrM}$, for 15 days had no effect on body weight gain in rats but had significant elevation in chickens like the current study and the difference between the two species is probably due to differences in the metabolism and function of creatine. This was obvious in a six-week study conducted by Stahle et al. (2003) to determine the feed efficiency and carcass quality of broilers supplemented creatine monohydrate where Stahle et al. (2003) stated that the feed efficiency of chicks fed diet $(0.63 \%$ creatine weeks $4-6)$ was superior to that of birds fed diet without creatine (control), during week four of the experiment and authors concluded that feed efficiency was improved from the third week to the fourth one. The current study was contrary to the results stated by Xia et al. (2012), who indicated that $\mathrm{CMH}$ supplementation didn't affect the average daily weight gain, average daily feed intake or feed efficiency and breast muscle or thigh muscle percentage of broilers.

\section{Conclusion:}

Based on the results of the current research, the authors concluded that dietary supplementation of $0.1 \%$ HMB-Ca improved growth performance parameters in terms of TFI, TBWG, TBW and TFCR compared to creatine supplemented group and the control group. HMB-Ca offers significant lower total feed intake (low dietary costs), significant better total feed conversion ratio, better total body weight gain and subsequently better average total body weights. The better growth performance offered by HMB is followed by the performance of creatine $(0.1 \%)$ compared to the control group. The performance of HMB as well as creatine in broiler chicks needs further work to investigate the histopathological changes induced by each one in the doses tried and even higher doses. Creatine induce some biochemical changes in blood parameters in the form of significantly high results of both triglyceride and $\mathrm{T} 3$ at the end of the experiment in creatine supplemented group. Significant high results 
of ALT (mean) in the control group than in group 2 (HMB) on the $21^{\text {st }}$ day during feeding on grower diet were observed where, that significant results became fortunately insignificant at the $42^{\text {nd }}$ day. Rather than these changes, HMB and creatine supplementations had no effect on the other blood parameters, viz. AST, urea, creatinine, total protein, FFA, T4, T3/T4 ratio, TSH, uric acid, cholesterol, HDL and LDL, and pro inflammatory cytokines namely, IL6, IL2 and TNF- $\alpha$.

\section{REFERENCES}

Antolic, A., Roy, B.D., Tarnopolsky, M.A., Zernicke, R.F., Wohl, G.R., Shaughnessy, S.G., Bourgeois, J.M. 2007. Creatine Monohydrate Increases Bone Mineral Density in Young Sprague-Dawley Rats. Medicine \& Science in Sports \& Exercise, 39(5):816-820.

Ashour, E.A., Alagawany, M., Reda, F.M., AbdElHack, M.E. 2014. Effect of supplementation of Yucca Schidigera extract to growing rabbit diets on growth performance, carcass characteristics, serum biochemistry and liver oxidative status. Asian J. Anim. Vet. Adv., 9: 732742.

Baillie, A.G., Garlick, P.J. 1991. Responses of protein synthesis in different skeletal muscles to fasting and insulin in rats. Am. J. Physiol., 260:E891-E896.

Balsom, P.D., Soderlund, K., Sjodin, B., Ekblom, B. 1995. Skeletal muscle metabolism during short duration high-intensity exercise: influence of creatine supplementation. Acta Physiologica Scandinavica, 154: 303-310

Baracho, N.C.V., Castro, L.P., Borges, N.C., Laira, P.B. 2015. Study of renal and hepatic toxicity in rats supplemented with creatine. Acta Cirúrgica Brasileira, 30 (5): 313-318.

Bessman, S.P., Carpenter, C.L. 1985. The creatine-creatine phosphate energy shuttle. Annu. Rev. Biochem., 54: 831-862

Burtis, A., Carl, A., Edward, R., Ashwood, M.D. 1999. Tietz Textbook of Clinical Chemistry 3rd Edition.
Casey, A., Constantin-Teodosiu, D., Howell, S., Hultman, E., Greenhaff, P.L. 1996. Creatine ingestion favorably affects performance and muscle metabolism during maximal exercise in humans. American Journal of Physiology, 271: E31-37.

Chen, J., Wang, M., Kong, Y., Ma, H., Zou, S. 2011. Comparison of the novel compounds creatine and pyruvate on lipid and protein metabolism in broiler chickens. Animal, 5(7):1082-1089

Earnest, C.P., Almada, A.L., Mitchell, T.L. 1996. High -performance capillary electrophoresis-pure creatine monohydrate reduces blood lipid in men and women. Clin. Sci., 91:113-118.

Ferreira, L.G., De-Toledo-Bergamaschi, C., Lazaretti-Castro, M., Heilberg, I.P. 2005. Effects of creatine supplementation on body composition and renal function in rats. Medicine and Science in Sports and Exercise, 37(9):1525-1529.

Foye, O.T., Uni, Z., Ferket, P.R. 2006a. Effect of in ovo feeding egg white protein, betahydroxy-beta-methylbutyrate, and carbohydrates on glycogen status and neonatal growth of turkeys. Poult. Sci., $85: 1185-1192$.

Foye, O.T., Uni, Z., McMurtry, J.P., Ferket, P.R. 2006b. The effects of amniotic nutrient administration, "in ovo feeding" of arginine and/or $\beta$-hydroxy- $\beta$-methyl butyrate (HMB) on insulin-like growth factors, energy metabolism and growth in turkey poults. Int. J. Poult. Sci., 5:309317.

Hultman, E., Soderlund, K., Timmons, J.A., Cederblad, G., Greenhaff, P.L. 1996. Muscle creatine loading in man. J Appl Physiol., 81:232-237.

Ipsiroglu, S.O., Stromberger, C., Ilas, J., Hôger, H., Mûhl, A., Ipsiroglu-Stockler, S. 2001. Changes of tissue creatine concentrations upon oral supplementation of creatine-monohydrate in various animal species. Life Sciences, 69: 1805-1815.

Kaplan, R.M. 1984. the connection between clinical health promotion and health status: A critical overview. American psychologist, 39:755-765. 
Kudair, I.M., Al-Hussary, N.A.J. 2010. Effect of Blood vaccination on some biochemical parameters in broiler chickens. Iraqi J. Vet. Sci., 24: 59-64

Lambert, W.V., Ellis, N.R., Black, W.H., Titus, H.W. 1936. The sole of nutrition in genetic research. The American Society of Animal Production,

29:236. http://jas.fass.org/cgi/reprin/1936b/1/236a.

Lauterio, T.J., Decuypere, E., Scanes, C.G. 1986. Growth, protein synthesis and plasma concentrations of growth hormone, thyroxine and triiodothyronine in dwarf, control and growth selected strains of broiler-type domestic fowl. Comp. Biochem. Physiol. A Comp. Physiol., 83:627-632.

Maughan, R.J., King, D.S., Lea, T. 2004. Dietary supplements. Journal of Sports Sciences, 22: 95-113.

Moghadam, A.Z., Nazem, H., Karimi, I., Darani, I.A., Hassanpour, H. 2008. Study of Oral Creatine Monohydrate Supplementation on Growth Performance and Histopathological Assessment in Rats and Chickens. Journal of Biological Sciences, 8: 436-440.

Moraes, R. Bavel, D.V., Moraes, B.S., Tibiriçá, E. 2014. Effects of dietary creatine supplementation on systemic microvascular density and reactivity in healthy young adults. Nutrition Journal, 13:115-124.

Mullur, R., Liu, Y.Y., Brent G.A. 2014. Thyroid hormone regulation of metabolism. Physiol Rev., 94(2):355-382.

National Research Council (NRC) (1994). Nutrient requirements of poultry. Ninth Ed, Washington, DC National academy press.

Nissen, S., Fuller, J.C., Sell, J., Ferket, P.R., Rives, D.V. 1994a. The effect of $\beta$ hydroxy- $\beta$-methylbutyrate on growth, mortality, and carcass qualities of broiler chickens. Poult. Sci., 73:137-155.

Nissen, S., Morrical, D., Fuller, J.C. 1994b. The effects of the leucine catabolite $\beta$-hydroxy$\beta$-methylbutyrate on the growth and health of growing lambs. J. Anim. Sci, 77(Suppl. 1):243

Ostaszewski, P., Kostiuk, S., Balasińska, B., Jank, M., Papet, I., Glomot, F. 2000. The leucine metabolite 3-hydroxy-3-methylbutyrate (HMB) modifies protein turnover in muscles of laboratory rats and domestic chickens in vitro. J. Anim. Physiol. Anim. Nutr., 84:1-8.

Pause, A., Belsham, G.J., Gingras, A.C., Donze, O., Lin, T.A., Lawrence, J.J., Sonenberg, N. 1994. Insulin-dependent stimulation of protein synthesis by phosphorylation of a regulator of 5'-cap function. Nature, 371:762-767.

Peterson, A.L., Qureshi, M.A., Ferket, P.R., Fuller, J.C. 1999. In vitro exposure with $\beta$ hydroxy- $\beta$-methylbutyrate enhances chicken macrophage growth and function. Vet. Immunol. Immunopathol, 67:67-78.

Portal, S., Eliakim, A., Nemet, D., Halevy, O., Zadik, Z. 2010. Effect of HMB supplementation on body composition, fitness, hormonal profile and muscle damage indices. J. Pediatr. Endocrinol. Metab., 23:641-650.

Portal, S., Zadik, Z., Rabinowitz, J., PilzBurstein, R., Adler-Portal, D., Meckel, Y., Cooper, D. M., Eliakim, A., Nemet, D. 2011. The effect of HMB supplementation on body composition, fitness, hormonal and inflammatory mediators in elite adolescent volleyball players: a prospective randomized, double-blind, placebo-controlled study. Eur J Appl Physiol, 111(9):2261-2269.

Robertson, S.P., Twigg, S.R., Sutherland-Smith, A.J., Biancalana, V., Gorlin, R.J., Horn, D., Kenwrick, S.J., Kim, C.A., Morava, E., Newbury-Ecob, R. Orstavik, K.H., Quarrell, O.W., Schwartz, C.E., Shears, D.J., Suri, M., Kendrick-Jones, J., Wilkie, A.O. 2003. Localized mutations in the gene encoding the cytoskeletal protein filamin A cause diverse malformations in humans. Nature Genetics, 33: 487491.

Smith, J.W., Evans, A.T., Costall, B., Smythe, J.W. 2002. Thyroid hormones, brain function and cognition: A brief review. Neurosci. Biobehav. Rev, 26:45-60.

Stahl, C.A., Greenwood, M.W., Berg, E.P. 2003. Growth Parameters and Carcass Quality of Broilers Fed a Corn-Soybean Diet Supplemented with Creatine Monohydrate. 
International Journal of Poultry Science, 2 (6): 404-408

Steiner, G., Vranic, M. 1982. Hyperinsulinemia and hypertriglyceridemia, a vicious cycle with atherogenic potential. Int. J. Obesity, 6: 117-124.

Taes, Y.E., Delanghe, J.R., Wuyts, B., Van-DeVoorde, J., Lameire, N.H. 2003. Creatine supplementation does not affect kidney function in an animal model with preexisting renal failure.

Takahashi, T., Nowakowski, F.L.S., Caviness, V.S. 1995. The Cell Cycle of the Pseudostratified Ventricular Epithelium of the Embryonic Murine Cerebral Wall. The Journal of Neuroscience, 15: 6046-6057.

Tarnopolsky, M.A., Bourgeois, J.M., Snow, R., Keys, S., Roy, B.D., Kwieeien, J.M., Turnbull, J. 2003. Histological assessment of intermediate and long-term creatine monohydrate supplementation in mice and rats. American Journal of Physiology. Regulatory, Integrative and Comparative Physiology, 285: 762-769.

Tatara, M.R. 2008. Neonatal programming of skeletal development in sheep is mediated by somatotrophic axis function. Exp. Physiol., 93:763-772.

Tietz, N.W. 1995. Clinical Guide to Laboratory Tests, 3rd Edition, W.B. Saunders, Philadelphia, PA.

Tsuruzoe, K., Araki, E., Furukawa, N., Shirotani, T., Matsumoto, K., Kaneko, K.,
Motoshima, H., Yoshizato, K., Shirakami, A., Kishikawa, H., Miyazaki, J., Shichiri, M. 1998. Creation and characterization of a mitochondrial DNA-depleted pancreatic betacell line: Impaired insulin secretion induced by glucose, leucine, and sulfonylureas. Diabetes, 47:621-631.

Uni, Z., Ferket, P.R., Tako, E., Kedar, O. 2005. In ovo feeding improves energy status of lateterm chicken embryos. Poult. Sci., 84:764-770.

Van-Koevering, M.T., Dolezal, H.G., Gill, D.R., Owens, F.N., Strasia, C.A., Buchanan, D.S., Lake, R., Nissen, S. 1994. Effects of beta-hydroxy-beta-methyl butyrate on performance and carcass quality of feedlot steers. J. Anim. Sci., 72:1927-1935.

Wyss, M., Kaddurah-Daouk, R. 2000. Creatine and creatinine metabolism. Physiological Reviews, 80: 1107-1213.

Xia, W.G., Abdullahi, A.Y., Zuo, J.J., Chen, L., Feng, D.Y. 2012. Effect of creatine monohydrate on growth performance, carcass characteristics and meat quality of yellow-feathered broilers. Journal of Animal and Veterinary Advanced, 11(23): $4382-4388$

Young, D.S. 1995. Effects of Drugs on Clinical Laboratory Tests, 4th Edition, AACC Press, Washington, D.C.

Young, D.S. 2001. Effects of disease on Clinical Lab. Tests, 4th ed. AACC 2001. 